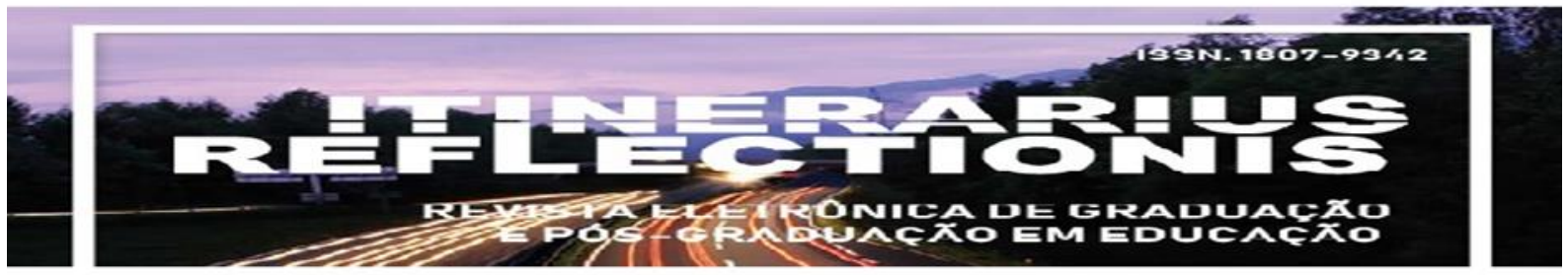

Volume, 15, número1, ano 2019

\title{
A PERCEPÇÃO DOS PROFESSORES SOBRE A ESCOLA DE TEMPO INTEGRAL: O CASO DO CEPI AMÉLIA ISSA
}

\author{
Wender da Silva Caixeta ${ }^{1}$ \\ Cristiane Maria Ribeiro ${ }^{2}$
}

\begin{abstract}
Resumo: Este trabalho objetivou analisar as percepções de professores acerca da Escola Pública de Tempo Integral (ETI) tendo como objeto de estudo Centro de Ensino em Período Integral Amélia Issa, localizada em Orizona-Go, pertencente à Rede Estadual de Educação de Goiás. A pesquisa de natureza qualitativa foi realizada sob a perspectiva de estudo de caso e teve como metodologia a análise documental, a observação participante natural e aplicação de questionários aos professores da escola investigada. Os dados mostraram que a maioria dos professores consideram a ETI muito necessária ao contexto escolar, embora suas percepções ainda apontem marcas assistencialistas que sustentam esta concepção. Constatamos também a precariedade nas condições de trabalho no que tange à falta de espaços específicos para a execução das atividades variadas, o que implica na reorganização dos espaços e tumulto na escola. Concluímos que o estado exerce uma atuação tênue no tocante aos subsídios para manutenção desta organização escolar. Para tanto, nossos achados, enfatizam que não basta estender a jornada escolar no tocante à carga horária, é preciso que haja espaços físicos apropriados e recursos pedagógicos para a melhoria desta organização escolar enquanto política pública.
\end{abstract}

Palavras-chave: Escola de Tempo Integral, Políticas Públicas; Professores.

\section{THE TEACHERS 'PERCEPTION ABOUT THE SCHOOL OF A COMPREHENSIVE TIME: THE CASE OF CEPI AMÉLIA ISSA}

\begin{abstract}
This work aimed to analyze the teachers' perceptions about the Public School of Integral Time (ETI) with the object of study Amelia Issa Integral Education Center, located in Orizona-Go, belonging to the State Educational Network of Goiás. qualitative nature was carried out from the perspective of a case study and had as methodology the documentary analysis, the natural participant observation and the application of questionnaires to the teachers of the investigated school. The data
\end{abstract}

\footnotetext{
${ }^{1}$ Mestrando em Conservação de Recursos Naturais do Cerrado pelo Instituto Federal Goiano e graduado em Licenciatura em Ciências Biológicas pela mesma instituição. É professor vinculado à Secretaria Municipal de Educação de Orizona na condição de assessor administrativo. wendersilvacaixeta@gmail.com

${ }^{2}$ Doutora em Educação pela Universidade Federal de São Carlos (UFSCAR), professora do Instituto Federal Goiano. cristiane.maria@ifgoiano.edu.br
} 


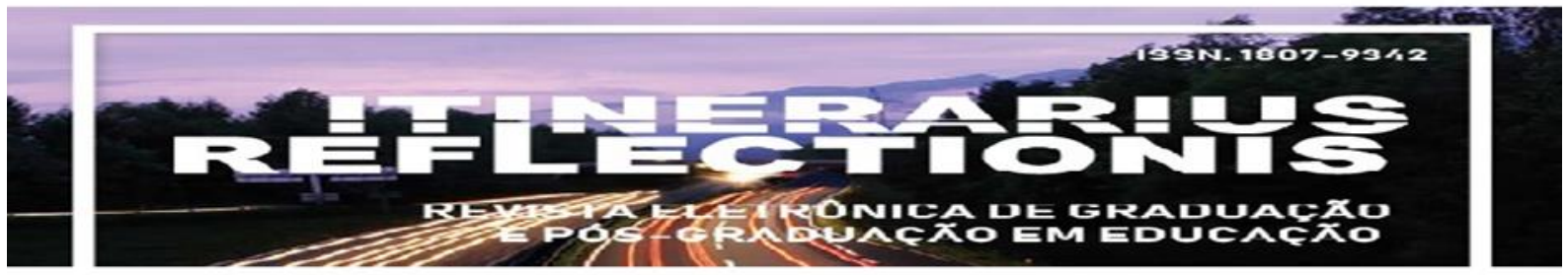

Volume, 15, número1, ano 2019

showed that most teachers consider the TSI much needed in the school context, although their perceptions still point to assistentialist brands that support this conception. We also note the precariousness of working conditions regarding the lack of specific spaces for the execution of varied activities, which implies the reorganization of spaces and turmoil in school. We conclude that the state exerts a tenuous action regarding the subsidies for maintenance of this school organization. Therefore, our findings emphasize that it is not enough to extend the school day regarding the workload, it is necessary that there be appropriate physical spaces and pedagogical resources for the improvement of this school organization as a public policy.

Keywords: Full Time School, Public Policies; Teachers.

\section{INTRODUÇÃO}

O movimento Escola Nova propagava, durante o século XX, pressupostos ideológicos que atribuíam maior importância ao aluno como sujeito ativo no processo de escolarização (LIBÂNEO, 2014). Cavaliere (2002, p. 252) acerca desse contexto relata que "as novas ideias em educação questionavam o enfoque pedagógico até então centrado na tradição, na cultura intelectual e abstrata, na autoridade" em um contexto ligado "à generalização e laicização da educação escolar alcançada na Europa e nos Estados Unidos" (CAVALIERE 2002, p.252) no final do século XIX, período de difusão dos ideais neoliberalistas. Líbâneo (2014) menciona que o escolanovismo evidenciou o aluno nas suas várias dimensões, diante do contexto social de expansão da indústria, intensificação da urbanização e desenvolvimento de uma classe operária. Desta forma, por meio deste cenário,

(...) foi disseminada a ideia de que a escola precisava adequar-se valorizando a ligação entre pensamento e prática, desenvolvendo práticas de cooperação como uma das exigências do trabalho na indústria. Ou seja, constitui-se uma escola centrada no fazer, na atividade da criança, nas suas necessidades, nos seus interesses, tal como foi formulada nos Estados Unidos por John Dewey (LIBÂNEO, 2014, p. 3).

A filosofia do pensador John Dewey (1859-1952) exerceu grande influência sobre a Escola Nova liderada no Brasil por Anísio Teixeira e Darcy Ribeiro que edificaram uma nova forma de organização escolar com o intuito de exercer a educação integral (LIBÂNEO,2014; SILVA, RODRIGUES E MOURA, 2015; SILVA, 2011). 


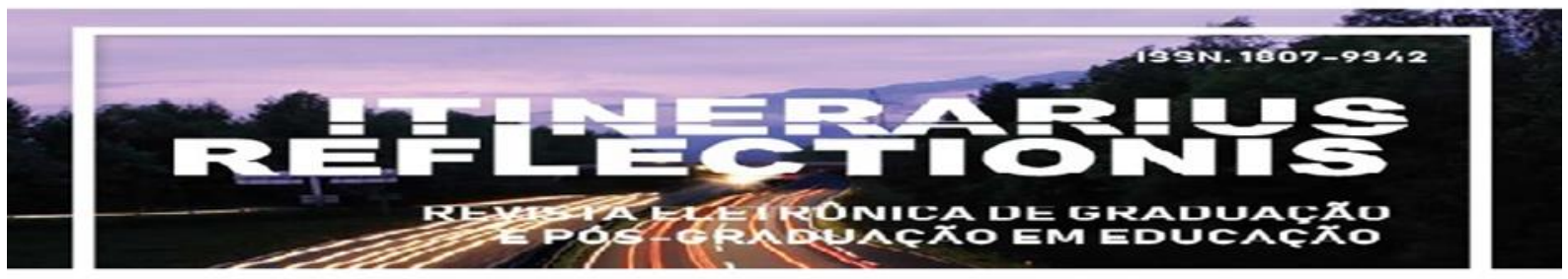

Volume, 15, número1, ano 2019

Libâneo (2014) traz que Anísio Teixeira foi figura importante na consolidação da

Escola de Tempo Integral no Brasil ao fundar em 1950 o Centro Educacional Carneiro Ribeiro (CECR), em Salvador, Bahia, com a pretensão de acolher 1.000 estudantes, dentre crianças e adolescentes carentes dos bairros periféricos no período de $07 \mathrm{~h} 30 \mathrm{mim}$ às $16 \mathrm{~h} 30 \mathrm{~min}$ e residência que comportasse 200 alunos que necessitavam de internato, numa estrutura dividida em Escola Classe para o ensino formal e Escola Parque voltada ao ensino profissionalizante.

Esta política pública se consolidou em detrimento do apoio financeiro do governo à época e foi espelho para experiências de instituições de tempo integral em Brasília na década de 1960 e no Rio de Janeiro nos anos 1980 por Darcy Ribeiro (SANTOS, 2009). Muito embora, com mudanças no cenário político, Carbello e Ribeiro (2014) afirmam que o projeto era audacioso para os cofres e, por isso, não se expandiu.

Segundo Santos (2009 p.17), Teixeira concebia o projeto como um avanço no campo das políticas públicas para a educação, pois previa a preparação dos alunos para a vida, em especial o mercado de trabalho mediante a intensificação da industrialização no Brasil.

A legislação para a escola de tempo integral foi definida apenas após a Constituição Federal, promulgada em 1988 e oito anos mais tarde, por meio da Lei de Diretrizes e Bases da Educação Brasileira (LDB) em 1996, a qual instituiu o Plano Nacional de Educação e a Conferência Nacional de Educação destinados ao fomento de propostas voltadas à melhoria da educação e, abordaram a ampliação da jornada escolar. (BRASIL, 1988; BRASIL, 1996, CONAE, 2014, PNE-2014).

A Lei de Diretrizes e Bases da Educação Nacional (LDB) regulamenta que a educação infantil deve ter jornada diária de 07 horas para a jornada de tempo integral, conforme artigo 31, parágrafo III - incluso pela Lei n 12.796, de 2013 (BRASIL, 1996; BRASIL 2013).

Quanto ao ensino fundamental, a legislação prevê a facultatividade para a ampliação da jornada escolar, conforme no Artigo 34 da LDB: 


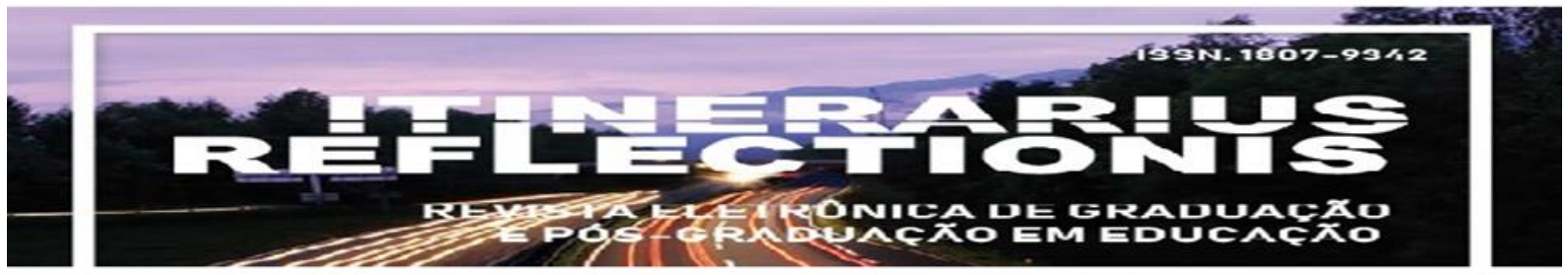

Volume, 15, número1, ano 2019

\begin{abstract}
Art. 34. A jornada escolar no ensino fundamental incluirá pelo menos quatro horas de trabalho efetivo em sala de aula, sendo progressivamente ampliado o período de permanência na escola.

$\S 1^{\text {o }}$ São ressalvados os casos do ensino noturno e das formas alternativas de organização autorizadas nesta Lei.

$\S 2^{\circ} \mathrm{O}$ ensino fundamental será ministrado progressivamente em tempo integral, a critério dos sistemas de ensino (BRASIL, 1996).
\end{abstract}

A aprovação do Plano Nacional de Educação (PNE), instituído pela LDB, em 2001 traz uma definição explícita na qual aborda que a escola de tempo integral é considerada a organização escolar em que a jornada de permanência do aluno seja no mínimo de 7 horas diárias para a educação infantil e ensino fundamental (BRASIL, 2001).

O último PNE, aprovado em 2014 estabelece metas quantificadas para que haja progressiva ampliação da jornada escolar. Aprovado pela Lei 13.005/14, traz na meta $\mathrm{n}^{\circ} 6$ a promoção da escola de tempo integral em $50 \%$ das escolas públicas de modo a atender $25 \%$ da população escolar e reafirma que a escola de tempo integral deve funcionar em período igual ou superior a 7 horas diárias para que seja considerada uma escola de tempo integral (PNE, 2014; BRASIL, 2011).

Além do exposto, a CONAE, Conferência Nacional de Educação, realizada em novembro de 2014, reafirma o período de 7 horas diárias para o funcionamento das escolas em tempo integral e coloca as instâncias municipal, estadual e federal como responsáveis por promoverem esta política e realizarem as adequações na infraestrutura e a formação de pessoal para a implantação desta organização escolar (CONAE, 2014).

As propostas para ampliação da jornada escolar pelo Governo Federal estão inseridas no Programa "Mais Educação", instituído pela Portaria Interministerial n 17, de 24 de abril de 2007 e decretado somente em 27 de janeiro de 2010, cuja pretensão é desenvolver melhoria da aprendizagem na ampliação da permanência na escola, além de auxiliar na retirada 


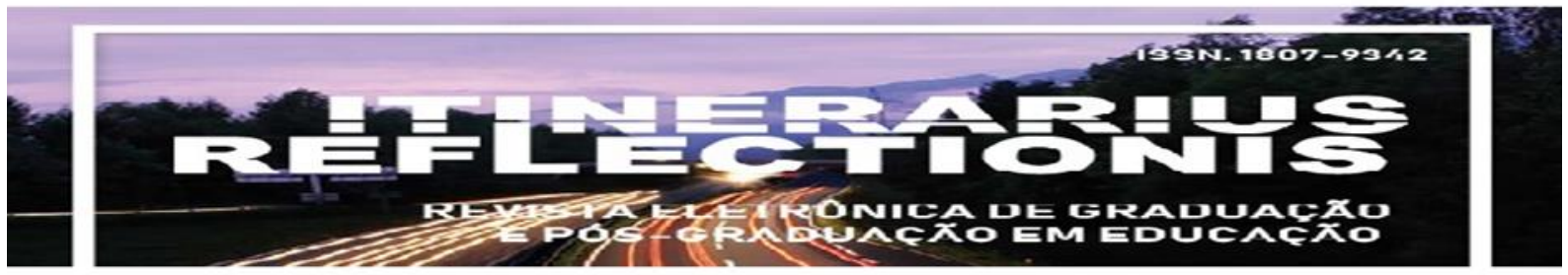

Volume, 15, número1, ano 2019

da população pobre das mazelas da sociedade (MEC, 2007; SILVA, 2013). Conforme portaria do MEC este programa é calcado nos seguintes objetivos:

I - apoiar a ampliação do tempo e do espaço educativo e a extensão do ambiente escolar nas redes públicas de educação básica de Estados, Distrito Federal e municípios, mediante a realização de atividades no contra turno escolar, articulando ações desenvolvidas pelos Ministérios integrantes do Programa;

II - contribuir para a redução da evasão, da reprovação, da distorção idade/série, mediante a implementação de ações pedagógicas para melhoria de condições para o rendimento e o aproveitamento escolar;

IV - prevenir e combater o trabalho infantil, a exploração sexual e outras formas de violência contra crianças, adolescentes e jovens, mediante sua maior integração comunitária, ampliando sua participação na vida escolar e social e a promoção do acesso aos serviços sócio-assistenciais do Sistema Único de Assistência Social SUAS; (MEC, 2007)

Paro et. al (1988, p.41) relatam que os projetos das escolas de tempo integral assumem uma função assistencialista ao oferecerem a ampliação do tempo da criança na escola, a fim de retirá-la da rua. Para os referidos autores, é necessário primeiramente oferecer "ensino de boa qualidade em período parcial - o que está muito longe de acontecer - para depois poderse falar em extensão da escolaridade para período integral".

Silva (2011) traz que esta organização escolar chegou em Goiás no ano de 2006 durante o governo de Alcides Rodrigues. A autora traz que a ETI na rede estadual de educação de Goiás foi implantada de forma apressada, com pouco diálogo com os envolvidos, apenas amparada por Portaria da Secretaria de Estado de Educação, Cultura e Esporte de Goiás e com a ausência de um projeto acerca desta proposta (SANTOS, 2009).

Santos (2009) apresenta que já em 2006, 77 unidades de ensino passaram a ter a jorna escolar estendida, compondo um conjunto de 18.000 alunos atendidos em período de 10 horas com atividades do núcleo básico de manhã e atividades de ampliação da aprendizagem, desportivas, culturais e auxílio nas atividades de casa no contra turno. Entre esses períodos, os alunos recebiam 3 refeições.

Segundo Silva (2011), a Escola de Tempo Integral foi motivado pelos Projetos Aprender e Projeto de Atividades Educacionais, no âmbito das políticas públicas que a SEDUCE (Secretaria de Estado de Educação, Cultura e Esporte de Goiás) executava e que 


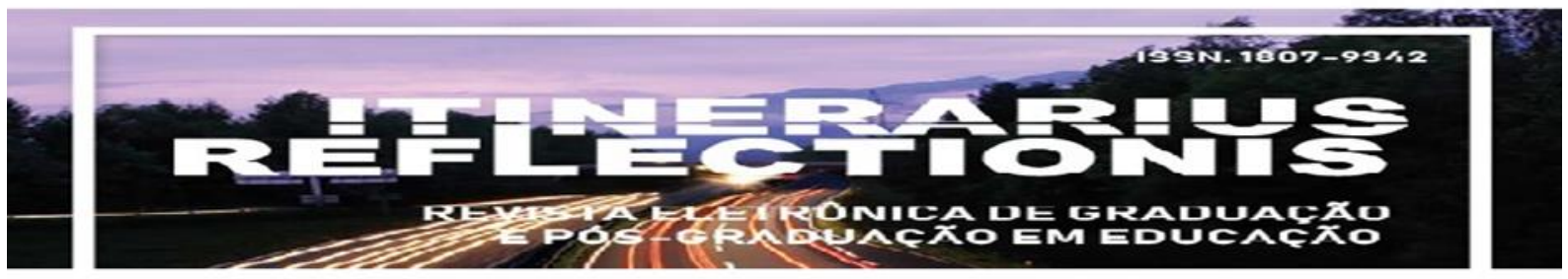

Volume, 15, número1, ano 2019

envolviam o retorno do aluno para a escola após o período comum das aulas, além da reorganização da rede escolar que disponibilizou prédios de escolas que foram desativadas.

Atualmente, são 120 instituições de ensino de tempo integral dentre os níveis fundamental e médio mantidas pelo Governo do Estado de Goiás. Em Orizona, encontra-se o Centro de Ensino em Período Integral Amélia Issa, o qual oferta o Ensino Fundamental de $1^{\circ}$ a $5^{\circ}$ ano em período integral. É a única instituição pública de tempo integral no município e objeto de estudo deste trabalho que teve como propósito analisar as percepções dos professores sobre a realidade desta organização escolar e provocar reflexões sobre este contexto.

De modo específico objetivamos analisar as percepções dos professores atuantes nesta escola no intuito de obter respostas às questões norteadoras: Como se configura as percepções dos professores sobre a presença da ETI na sociedade? Quais as implicações da extensão da jornada escolar no processo pedagógico segundo as percepções dos professores? Quais arcabouços legais e quais documentos regulamentam o funcionamento da escola de tempo integral investigada? Como é a rotina de atividades nesta instituição?

\section{METODOLOGIA}

Esta pesquisa de natureza qualitativa foi realizada sob a perspectiva de um estudo de caso utilizando o Centro de Ensino em Período Integral Amélia Issa, localizado em OrizonaGoiás, mantida pelo governo estadual como objeto de estudo. A pesquisa ocorreu durante o segundo semestre de 2016, período em que na escola havia 150 alunos matriculados. Recentemente a denominação de Centro de Ensino em Período Integral (CEPI) foi dada pela Lei $n^{\circ}$ 19.687, de 22 de junho de 2017 (GOIÁS, 2017) para as escolas que funcionam em tempo integral no estado de Goiás.

Para Gil (2008) o estudo de caso é utilizado como método para pesquisas que representam um contexto geral a partir de um contexto investigado de forma específica e aprofundada. Desta forma, destinamos a investigar a realidade adentrando as portas da escola de tempo integral, o CEPI Amélia Issa ao entendermos que contexto investigado pode representar a realidade de outras instituições da Rede Estadual de Educação de Goiás. 


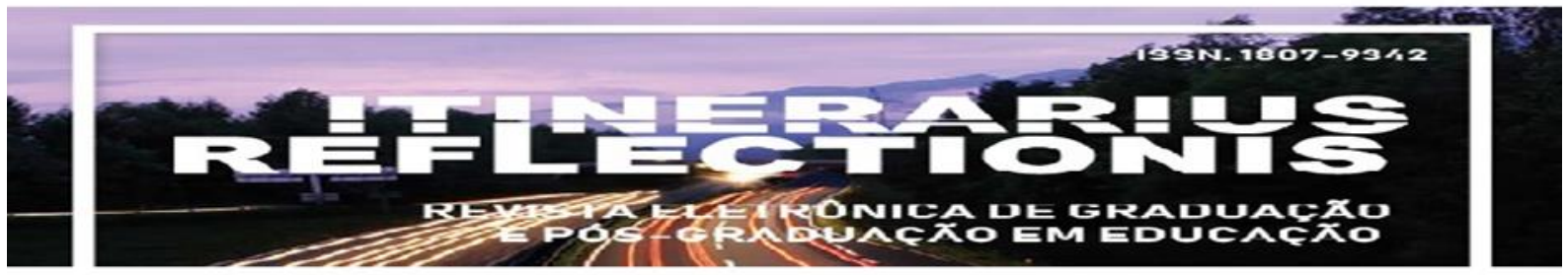

Volume, 15, número1, ano 2019

Como parte da metodologia, utilizamos a análise documental que segundo Sá-Silva, Almeida e Guindani (2009) não se restringe a documentos propriamente ditos, mas a uma leitura de vídeos, filmes, slides, fotografias e pôsteres, os quais contêm informações

importantes sobre o contexto investigado. Foram utilizados para esta metodologia os seguintes documentos para coleta dos dados: “Diretrizes Operacionais ${ }^{3}$ da Rede Estadual de Educação de Goiás", o "Projeto Político Pedagógico do Centro de Ensino em Período Integral Amélia Issa". Contudo, almejando obter informações mais precisas, constituiu parte desta análise o documento "Orientações Pedagógicas Preliminares"4.

Adotamos o método da Observação Participante Natural, proposto por Gil (2008, p.122) "quando o observador pertence à mesma comunidade ou grupo que investiga". Esse método foi utilizado por considerarmos necessário observar a rotina das atividades executadas na escola sem intervenção dos pesquisadores. Consideramos que a Observação Participante Natural constitui uma metodologia que possibilita maior compreensão do objeto de estudo uma vez que o observador, quando integrante do grupo investigado, pode ter facilidade de acesso a dados de domínio privado a um público alheio ao ambiente investigado (GIL, 2008).

O questionário também foi utilizado por concordarmos com Moysés e Moori (2007) ao considerarem um método abrangente para a população investigada e importante para embasar a pesquisa científica. Foi elaborado um questionário composto com 13 questões, contendo questões abertas e fechadas e aplicado a todo o público investigado, composto por 15 professores $^{5}$, segundo a aceitação dos membros pesquisados por meio do Termo de Consentimento Livre e Esclarecido.

\footnotetext{
${ }^{3}$ As Diretrizes Operacionais constituem um documento publicado pela Secretaria Estadual de Educação, Cultura e Esporte com orientações sobre a organização da rede de ensino em período delimitado pelo documento. No documento analisado, o período de vigência delimitado pelo documento utilizado para coleta de dados foi o biênio 2016-2017. Contudo, não nos ativemos a analisar diretrizes anteriores a este trabalho.

${ }^{4}$ Este documento constitui de orientações repassadas pela SEDUCE à equipe escolar para orientar como deverá ocorrer o trabalho com os componentes curriculares oriundos da extensão da carga horária.

${ }^{5}$ Devido a elaboração deste trabalho ser também de autoria de um dos profissionais que atuam na escola, este foi excluído do grupo de professores que responderam ao questionário.
} 


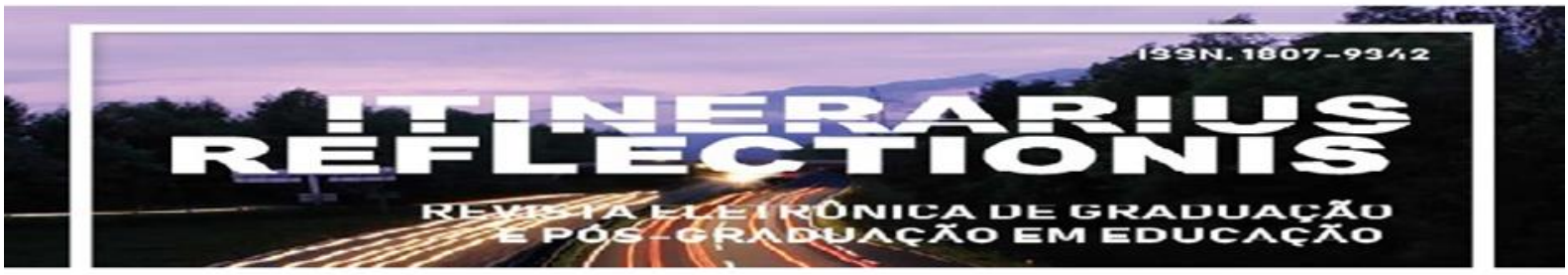

Volume, 15, número1, ano 2019

\section{RESULTADOS E DISCUSSÕES}

Objetivando identificar os documentos que regulamentam o funcionamento da Escola de Tempo Integral, foram analisados as Diretrizes Operacionais da Secretaria de Estado de Educação, Cultura e Esporte, o Projeto Político Pedagógico (PPP) da instituição e o documento "Orientações Pedagógicas Preliminares".

Com o intuito de evidenciar quais são os objetivos da proposta de tempo integral da rede estadual de Goiás, encontramos dados que coadunam com as posições de Libâneo (2014), ao apontar que a escola de tempo integral é marcada por uma função socializadora, além de buscar complementar a formação integral do aluno que envolve aspectos intelectuais, culturais e sociais. Este documento estabelece que

[...] a Educação em Tempo Integral do Estado de Goiás, além de ampliar o tempo de permanência dos estudantes e dos educadores na escola, visa a formação de crianças, adolescentes e jovens em sua inteireza, ou seja, considera o sujeito em sua condição multidimensional (GOIÁS, 2016, p. 39-41).

Contudo, não encontramos neste documento referência a nenhum aspecto que justifique de forma clara o funcionamento da ETI no contexto investigado. Há apenas menção a alguns critérios gerais para que as escolas passem a funcionar em tempo integral dentre eles ter baixo IDH (Índice de Desenvolvimento Humano) na região onde a escola está localizada. Estes dados permitem inferir que a população a ser atendida por esta organização escolar é de baixa renda. Conforme evidenciam Miranda e Santos (2012) ao tratarem que a ampliação da jornada escolar afasta o aluno de ameaças como a violência, nas quais regiões de baixo IDH são mais suscetíveis corroboram com nossos achados.

Quanto ao Currículo da escola, encontramos uma matriz curricular dividida em Núcleo Comum, baseado nas disciplinas básicas e Núcleo Diversificado, com as seguintes disciplinas: Orientação de Estudo; Iniciação Científica; Alfabetização/Letramento; 


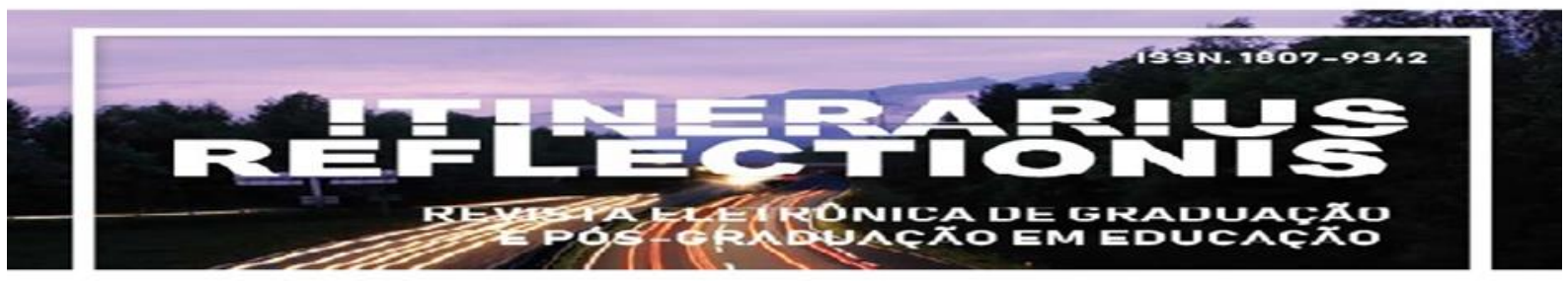

Volume, 15, número1, ano 2019

Numeramento; "Eletivas" e Atendimento Individualizado. Contudo, o documento não esclarece sistematicamente como deve funcionar esta proposta curricular.

Tabela 1. Matriz Curricular da ETI.

\begin{tabular}{|c|c|c|c|c|c|c|c|c|c|}
\hline & \multicolumn{9}{|c|}{ ESCOLAS DE TEMPO INTEGRAL - GOIÁS } \\
\hline & \multicolumn{9}{|c|}{ Matriz Curricular para Ensino Fundamental - Anos Iniciais - Integral } \\
\hline \multirow{18}{*}{ 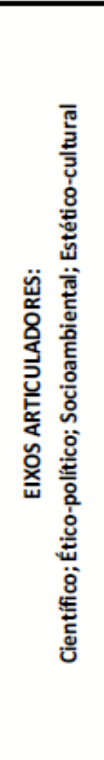 } & \multirow{10}{*}{ 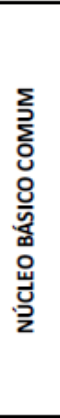 } & \multirow{2}{*}{ ÁREA DE CONHECIMENTO } & \multirow{2}{*}{$\begin{array}{l}\text { COMPONENTES } \\
\text { CURRICULARES }\end{array}$} & \multicolumn{5}{|c|}{ SÉRIES } & \multirow{2}{*}{$\mathrm{CH}$} \\
\hline & & & & 19 & 20 & 3으 & 4우 & 50 & \\
\hline & & \multirow{3}{*}{ LINGUAGENS, CÓDIGOS } & Língua Portuguesa & 5 & 5 & 5 & 5 & 5 & 1000 \\
\hline & & & Linguagens Artisticas & 3 & 3 & 3 & 3 & 3 & 600 \\
\hline & & & Educação Física & 3 & 3 & 3 & 3 & 3 & 600 \\
\hline & & $\begin{array}{l}\text { MATEMÁTICA E SUAS } \\
\text { TECNOLOGIAS }\end{array}$ & Matemática & 5 & 5 & 5 & 5 & 5 & 1000 \\
\hline & & $\begin{array}{l}\text { CIÊNCIAS DA NATUREZA E SUAS } \\
\text { TECNOLOGIAS }\end{array}$ & Ciências & 3 & 3 & 3 & 3 & 3 & 600 \\
\hline & & \multirow{2}{*}{$\begin{array}{l}\text { CIÊNCIAS HUMANAS E SUAS } \\
\text { TECNOLOGIAS }\end{array}$} & História & 3 & 3 & 3 & 3 & 3 & 600 \\
\hline & & & Geografia & 3 & 3 & 3 & 3 & 3 & 600 \\
\hline & & \multicolumn{2}{|c|}{ SUBTOTAL NÚCLEO COMUM } & 25 & 25 & 25 & 25 & 25 & 5000 \\
\hline & \multirow{7}{*}{ 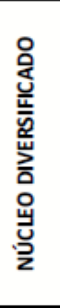 } & \multicolumn{2}{|c|}{$\begin{array}{l}\text { ESPAÇOS CURRICULARES EDUCATIVOS (RECREIO E ALMOÇO) } \\
\text { ATIVIDADES DE CONVIVÊNCIA, HÁBITOS DE HIGIENE E } \\
\text { ALIMENTARES }\end{array}$} & 10 & 10 & 10 & 10 & 10 & 2000 \\
\hline & & \multicolumn{2}{|l|}{ Alfabetização/Letramento } & 3 & 3 & 3 & 3 & 3 & 600 \\
\hline & & \multicolumn{2}{|l|}{ Numeramento } & 3 & 3 & 3 & 3 & 3 & 600 \\
\hline & & \multicolumn{2}{|l|}{ Orientação de Estudo } & 3 & 3 & 3 & 3 & 3 & 600 \\
\hline & & \multicolumn{2}{|l|}{ Ensino Religioso } & 1 & 1 & 1 & 1 & 1 & 200 \\
\hline & & \multicolumn{2}{|l|}{ Eletivas } & 10 & 10 & 10 & 10 & 10 & 2000 \\
\hline & & \multicolumn{2}{|c|}{ SUBTOTAL NÚCLEO DIVERSIFICADO } & 30 & 30 & 30 & 30 & 30 & 5800 \\
\hline & \multicolumn{3}{|c|}{ TOTAL GERAL } & 55 & 55 & 55 & 55 & 55 & 11000 \\
\hline & & $\begin{array}{l}\text { oso nos Anos Iniciais e Anos } \\
\text { CEB no } 7 / 201 \text { 0Art. } 15 \text { ₹ } 69\end{array}$ & $\begin{array}{l}\text { ss será ministrado co } \\
\text { rá trabalhado como }\end{array}$ & & & & & Go & $\begin{array}{l}2 / 2007 \\
\text { os da }\end{array}$ \\
\hline
\end{tabular}

Fonte: Diretrizes Operacionais da SEDUCE/GO (GOIÁS, 2016, p. 42)

A fim de obter dados mais precisos, esboçamos a Tabela 2 com os dados extraídos na análise do documento Orientações Pedagógicas Preliminares. Estes achados apresentam que, devido a alguns componentes curriculares, como Iniciação Científica, Alfabetização/Letramento e Orientação de Estudo, serem executados com reagrupamentos de alunos sem critérios definidos impossibilitam compreender com clareza a pretensão de reagrupar alunos, uma vez que uma turma contendo alunos de $1^{\circ}$ ao $5^{\circ}$ ano possuem maturidade diferente para absorver as propostas trabalhadas pelo professor, o que dificulta a organização metodológica das aulas executadas.

\footnotetext{
${ }^{6}$ Eletivas são disciplinas que a escola pode ofertar semestralmente priorizando as dimensões artística, cultural, afetiva e social. São organizadas por projetos pedagógicos elaborados pelos professores em observância à realidade da demanda na unidade escolar.
} 


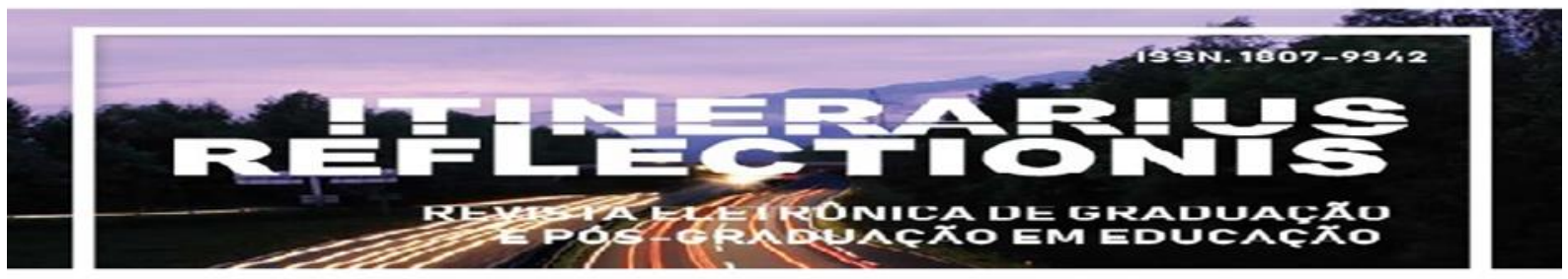

Volume, 15, número1, ano 2019

\begin{tabular}{|c|c|c|c|}
\hline \multicolumn{4}{|c|}{ ORGANIZAÇÃO DO CURRÍCULO NA ETI } \\
\hline $\begin{array}{c}\text { COMP. } \\
\text { CURRICULAR }\end{array}$ & $\begin{array}{l}\text { CARGA } \\
\text { HORÁRIA }\end{array}$ & OBJETIVO & $\begin{array}{c}\text { ORGANIZAÇÃO DA } \\
\text { DISCIPLINA }\end{array}$ \\
\hline Iniciação Científica & $\begin{array}{l}\text { Não } \\
\text { Informado }\end{array}$ & $\begin{array}{l}\text { Inserir os alunos no } \\
\text { ambiente da pesquisa } \\
\text { científica. }\end{array}$ & $\begin{array}{l}\text { Forma-se turmas de alunos do } 1^{\circ} \text { ao } 5^{\circ} \\
\text { ano, organizadas por um projeto } \\
\text { semestral que delimita os conteúdos a } \\
\text { serem estudados. } \\
\text { Acontece concomitante às disciplinas } \\
\text { de Alf./Letramento e Numeramento } \\
\text { para assim acontecer o reagrupamento } \\
\text { dos alunos. }\end{array}$ \\
\hline $\begin{array}{l}\text { Alfabetização/ } \\
\text { Letramento }\end{array}$ & $\begin{array}{l}3 \quad \text { Aulas } \\
\text { Semanais }\end{array}$ & $\begin{array}{l}\text { Trabalhar com os } \\
\text { gêneros textuais e a } \\
\text { importância da leitura e } \\
\text { escrita. }\end{array}$ & $\begin{array}{l}\text { Reagrupam os estudantes entre } 2^{\circ} \text { e } 3^{\circ} \\
\text { ano, } 4^{\circ} \text { e } 5^{\circ} \text { ano, salvo o } 1^{\circ} \text { ano para } \\
\text { formar turmas de no mínimo } 20 \text { alunos. } \\
\text { São considerados os resultados das } \\
\text { Avaliações Externas e Rendimento do } \\
\text { Aluno. }\end{array}$ \\
\hline Numeramento & $\begin{array}{l}3 \text { Aulas } \\
\text { Semanais }\end{array}$ & $\begin{array}{l}\text { Trabalhar contextos } \\
\text { sociais envolvendo a } \\
\text { matemática }\end{array}$ & $\begin{array}{l}\text { Reagrupam os estudantes entre } 2^{\circ} \text { e } 3^{\circ} \\
\text { ano, } 4^{\circ} \text { e } 5^{\circ} \text { ano, salvo o } 1^{\circ} \text { ano para } \\
\text { formar turmas de no mínimo } 20 \\
\text { alunos. São considerados os resultados } \\
\text { das Avaliações Externas e } \\
\text { Rendimento do Aluno. }\end{array}$ \\
\hline $\begin{array}{l}\text { Orientação De } \\
\text { Estudo }\end{array}$ & $\begin{array}{l}3 \quad \text { Aulas } \\
\text { Semanais }\end{array}$ & $\begin{array}{l}\text { Trabalhar as técnicas } \\
\text { de estudo. Segundo o } \\
\text { documento, "deve, em } \\
\text { primeiro lugar, à } \\
\text { estratégia de que } \\
\text { aprender a estudar é } \\
\text { condição primordial", }\end{array}$ & Não ocorre reagrupamento de alunos. \\
\hline $\begin{array}{l}\text { Atendimento } \\
\text { Individualizado }\end{array}$ & $\begin{array}{l}2 \quad \text { Aulas } \\
\text { Semanais }\end{array}$ & $\begin{array}{l}\text { Não informado em } \\
\text { nenhum documento }\end{array}$ & $\begin{array}{l}\text { Ocorre simultaneamente às aulas de } \\
\text { Orientação de Estudo. }\end{array}$ \\
\hline Eletivas & $\begin{array}{l}10 \quad \text { Aulas } \\
\text { Semanais }\end{array}$ & $\begin{array}{l}\text { "enriquecer, ampliar, } \\
\text { diversificar, desdobrar } \\
\text { conteúdos que devem } \\
\text { possibilitar } \\
\text { ao estudante a } \\
\text { construção do seu } \\
\text { próprio currículo e a } \\
\text { ampliação, } \\
\text { diversificação } \\
\text { e/ou aprofundamento } \\
\text { de conceitos" (GOIÁS, } \\
\text { 2016, págs. 26-27) }\end{array}$ & $\begin{array}{l}\text { São organizadas por um projeto } \\
\text { elaborado pelo professor em } \\
\text { cosonância com a equipe pedagógica } \\
\text { da unidade, sendo de duração semestral } \\
\text { com um momento de culminância no } \\
\text { fim do semestre a fim de apresentar os } \\
\text { resultados da disciplina. Os estudantes } \\
\text { podem optar por no mínimo } 2 \text { e no } \\
\text { máximo } 5 \text { eletivas. }\end{array}$ \\
\hline
\end{tabular}




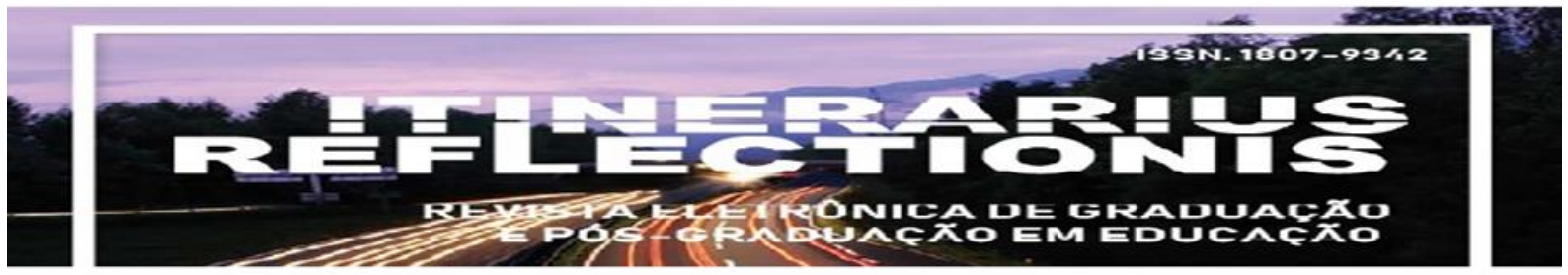

Volume, 15, número1, ano 2019

Tabela 2. Organização da grade curricular da ETI.

Fonte: Elaboração Própria

Julgamos importante analisar a carga horária cumprida por alunos e professores. Quanto ao corpo discente, a permanência do aluno deve ser de 10 horas diárias, com início das atividades às 7:00 h e término às 17:00 h, em aulas de 50 minutos, revezando entre os dois recreios de 15 minutos que são inclusos na carga horária de "Atividades de Convivência, Hábitos de Higiene e Alimentares" da matriz curricular.

Quanto à carga horária docente, o documento analisado apresenta o professor deve permanecer 40 horas semanais na instituição, com uma remuneração de 60 h/aulas envolvendo na carga horária períodos para planejamento pedagógico, estudo e reuniões de acompanhamento pedagógico com o grupo gestor da unidade escolar (GOIÁS, 2016). Estes critérios para a jornada do corpo docente foi definido pela Lei $\mathrm{n}^{\circ} 19.687$, de 22 de junho de 2017 (GOIÁs, 2017).

No documento analisado, encontramos que a Secretaria de Estado de Educação, Cultura e Esporte realizará momentos voltados à capacitação dos professores confome traz no documento: "promoção de políticas de formação continuada dos profissionais de educação de sua rede" (GOIÁS, 2016, p. 13).

A documentação analisada apresenta que o projeto de ETI na rede pública goiana, desde sua concepção aos dias atuais, ainda apresenta ausência de fatores que possam delimitar os funcionamento desta organização escolar e que acarreta a dificuldade do planejamento pedagógico dos professores.

Evidenciamos que é marcante a reorganização curricular e metodológica para o trabalho com as disciplinas da grade da escola o que traz pouca eficácia para as ações pedagógicas conforme tratam Santos (2009) e Castro e Lopes (2011).

Foi analisado o Projeto Político Pedagógico (PPP) da escola. Consideramos que este documento tem uma abordagem superficial para explanar sobre a proposta pedagócia da 


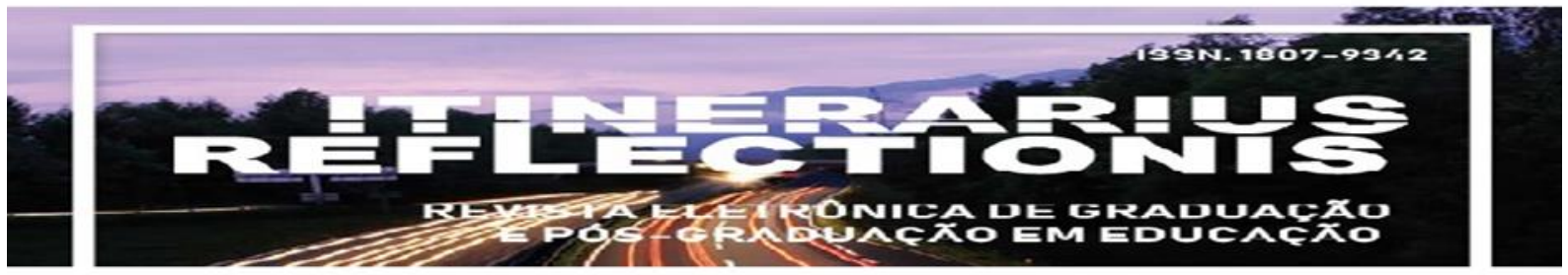

Volume, 15, número1, ano 2019

escola voltada a extensão da jornada escolar ao apenas afirmar que a escola é orgnaizaça segundo a

(...) promoção de atividades conjuntas e estabelecimento de condições adequadas para promover o desenvolvimento intelectual, psicológico, artístico, cultural, esportivo e de integração social de nossos educandos (PPP, 2016, p.9).

Foi identificado que a escola começou a ampliar a jornada escolar a partir de 2009. Quanto à organização das turmas e da proposta de educação integrla, o PPP têm caráter superficial e sintético relatando somente que a instiutição atende os alunos de $1^{\circ}$ ao $5^{\circ}$ ano em turno ampliado.

Por meio da observação, verificamos que a escola realmente atende os alunos com jornada diária de 10 horas e um dos fatores iniciais que nos chamou atenção se refere ao fato de que a modulação dos professores está incoerente com as diretrizes operacionais no tocante ao Atendimento Individualizado. O documento prevê que o professor deve ofertar dois atendimentos individualizados e assim, nos horários afixados na parede notou-se que os professores realizam 3 atendimentos individualizados simultâneos ao componente curricular Orientação de Estudo.

Constatamos que o reagrupamento de alunos acontece nos componentes curriculares Numeramento, Alfabetização/Letramento, Iniciação Científica e Eletivas e que há um certo tumulto de alunos no corredor e no pátio até se acomodarem em suas respectivas salas, fato que acarreta uma perca no horário das aulas. No período deste estudo foram ofertadas as seguintes disciplinas eletivas: Mídias, Xadrez, Dança, Handebol, Futsal, Inglês e Jogos Desportivos.

O espaço físico da escola é precário, pois a quadra de cimento grosso e a céu aberto dificulta a permanência e a realização de certas atividades tanto para professores quanto para alunos, além de que a presença de apenas uma quadra gera um certo tumulto entre as eletivas de Futsal e Handebol que necessitam do mesmo espaço e acontecem concomitantemente na maioria das vezes. Diante disso as professoras revezam de forma que enquanto uma turma (futsal ou handebol) utiliza o espaço da quadra, a outra turma realiza um trabalho na sala de aula ou aguarda realizando atividades recreativas no pátio da escola. 


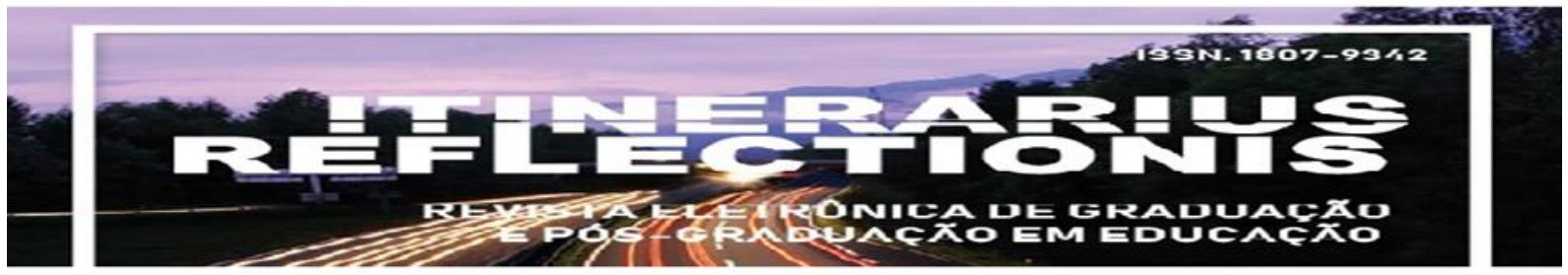

Volume, 15, número1, ano 2019

A observação também nos permitiu evidenciar que antigos espaços foram adaptados e reorganizados para a criação dos ambientes para atender a proposta de funcionamento. A sala de Iniciação Científica (que também acomoda os alunos de Futsal) era uma sala de vídeo; o almoxarifado onde eram acomodados os antigos arquivos atende à sala de professores para planejamento e estudo; a sala de Atendimento Educacional Especializado foi desativada e reorganizado o espaço para sala de leitura. Essa reorganização é constante no horário de almoço e das eletivas, visto que presenciamos os professores arrastando carteiras e trazendo objetos para a sala de aula, a fim de adaptar o ambiente para o trabalho.

Vale ressaltar que no horário de almoço os alunos aguardam em sala de aula até almoçarem no refeitório, um espaço que feito uma extensão do pátio com mesas e carteiras, acomodando em média três turmas por vez. Salientamos que durante esta etapa do presente trabalho, houve momentos de chuva e, contudo, percebemos que o espaço molha bastante, pois não há paredes, dificultando o trabalho das merendeiras para servirem os alunos. Após realizarem as refeições, os alunos retornam para a sala de aula e reorganizam os espaços arrastando carteiras para se acomodarem ou descansarem em colchonetes. Apenas três salas têm colchonetes em condições razoáveis, e, nas demais salas, os alunos e professores improvisam com lençóis trazidos de casa.

Posto isso, mesmo que a escola tenha a infraestrutura de outra instituição desativada, a dependência física carece de adaptações para atender melhor o alunado, uma vez que encontram banheiros masculino e feminino com poucos sanitários, auditório pequeno, salas ambientes pequenas (devido à reorganização do espaço), quadra a céu aberto, computadores sem suporte, dentre outros.

Os dados vão ao encontro de Silva (2011) ao estudar a trajetória da ETI na rede pública de ensino goiana e evidenciar que as experiências de escolas de tempo integral foram implantadas utilizando espaços de escolas desativadas há certo tempo, havendo apenas a adequação do Projeto Político Pedagógico. É nesse sentido, que a autora menciona que a escola de tempo integral, poderia ser consolidada, enquanto política pública, quando "houver recursos financeiros suficientes para a ampliação de espaços escolares diversificados como laboratórios de línguas, de informática, de ciências equipados” (SILVA, 2011, p. 93) 


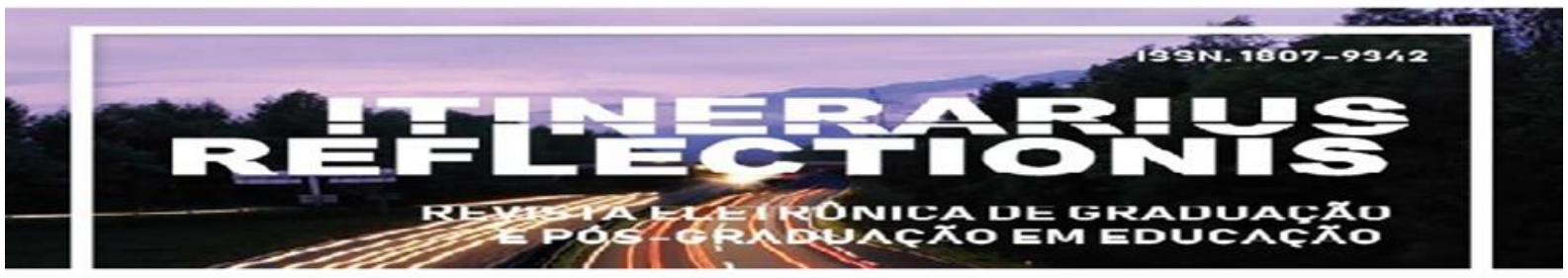

Volume, 15, número1, ano 2019

No decorrer da observação, consideramos importante os dizeres de Castro e Lopes (2011 p.277) ao mencionar que "quanto mais avançávamos na pesquisa menos certeza tínhamos de que essa melhoria, decorrente da maior extensão do tempo de permanência discente na escola, realmente ocorreria", uma vez que os resultados do trabalho das referidas autoras e de Santos (2009) corroboram o recorrente improviso para a articulação das atividades desenvolvidas conforme constatamos na observação.

Concordamos ainda com Santos (2009) ao tratar que a jornada de dez horas diárias, como é o caso desta instituição, é excessiva e pode contribuir para o tumulto e indisciplina na escola.

Foram aplicados questionários a 15 professores abrangendo todo o corpo docente da unidade escolar. Primeiramente, julgamos necessário identificá-los quanto ao tempo de docência. Os dados coletados na tabela abaixo apresentaram um corpo docente heterogêneo, sendo que o mais novo tem 1 ano e o mais velho 24 anos e 6 meses de docência e 01 pesquisado não respondeu à identificação.

Tabela 3. Tempo de docência em anos dos professores atuantes na Escola de Tempo Integral.

Tempo de Docência

Número de professores da ETI

\begin{tabular}{|c|c|}
\hline 01 a 05 anos & 6 \\
\hline 05 a 10 anos & 2 \\
\hline 10 a 15 anos & 0 \\
\hline 15 a 20 aos & 4 \\
\hline 20 a 25 anos & 2 \\
\hline
\end{tabular}

Fonte: Elaboração própria.

Quanto a idade dos mesmos, a faixa etária varia de 21 a 53 anos. Esses dados evidenciam que há uma parcela significativa de professores recém-atuantes na profissão e que iniciaram a profissão nesta instituição, conforme o gráfico: 


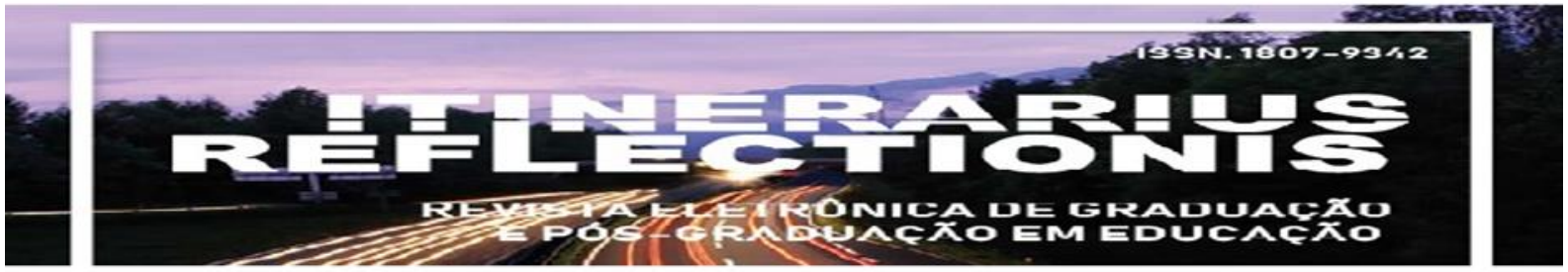

Volume, 15, número1, ano 2019

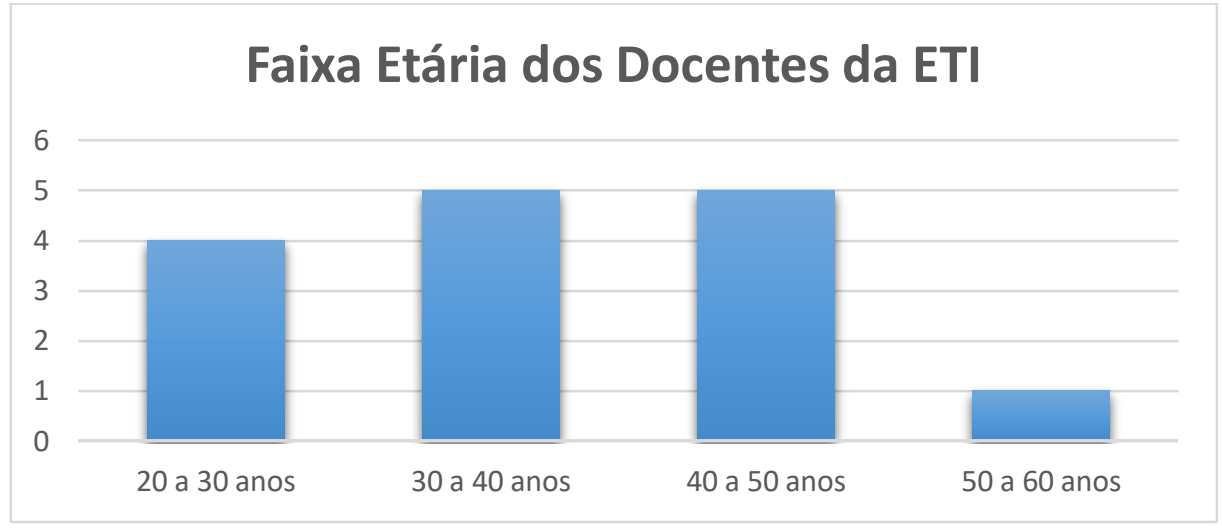

Fonte: Elaboração própria.

Consideramos importante analisar o tempo de docência da população na escola de tempo integral investigada. Os dados apontam que o professor mais novo na instituição tem 03 meses e o mais velho 8 anos. Esses achados estão esboçados no gráfico abaixo e demonstram que de acordo com a análise do PPP, há 2 professores que acompanharam o início da implantação do projeto escola de tempo integral.

Gráfico 2. Tempo de Docência

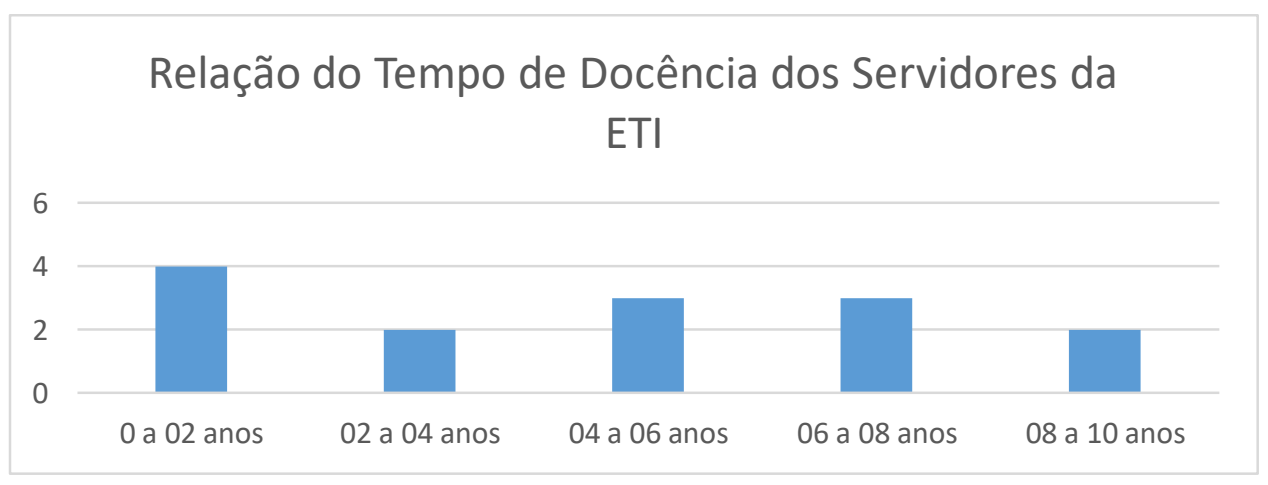

Fonte: Elaboração Própria. 


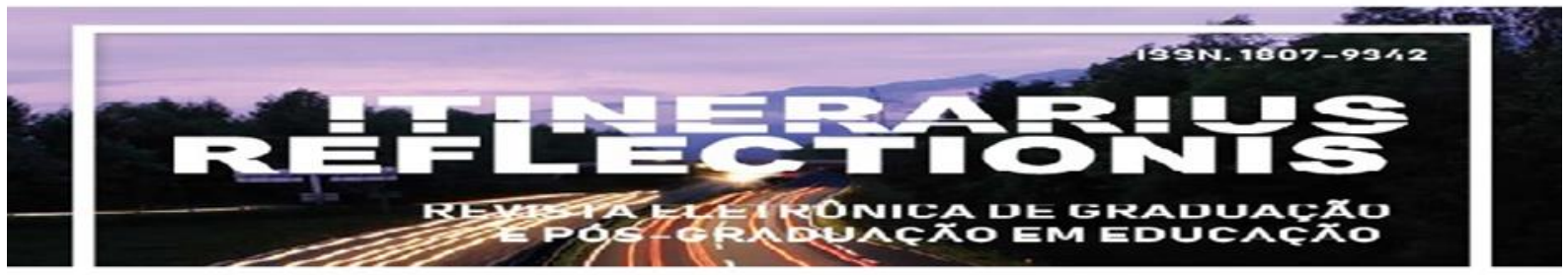

Volume, 15, número1, ano 2019

Com o intuito de obter uma percepção acerca do perfil do docente da ETI, questionamos aos entrevistados a relação de vínculo empregatício e evidenciamos que 53,33\% dos respondentes são contratados e iniciantes na carreira docente.

No que se refere à jornada de trabalho na ETI, todos os professores responderam que trabalham com carga horária de 60 horas/aulas cumprindo 40 horas de efetivo trabalho in loco, o que corrobora com as Diretrizes da Secretaria de Educação, apontadas no início da exposição destes resultados.

A fim de analisar a importância que os professores destinam à ETI, verificamos que $80 \%$ dos professores consideram-na muito necessária em oposição a $20 \%$ que afirmaram ser pouco necessária. Desta forma encontramos professores sensibilizados com o contexto no qual a escola de tempo integral se insere ao ofertar assistência ao alunado, que em sua maioria são de famílias carentes da cidade, fato que sustenta a posição dos mesmos ao considerarem uma organização necessária à sociedade, mesmo que a atuação pedagógica seja colocada em segundo plano.

Propusemos a verificar como os pesquisados compreendem a relação entre escola e família. Dados de 93,33\% esboçam que os professores compreendem que escola perdeu sua identidade, uma vez que o docente assume funções de responsabilidade da família ao acentuarem que os alunos permanecem o dia todo na escola e passam pouco tempo com a família. Por outro lado, encontramos professores que sensibilizam com a realidade da comunidade de alunos, que em sua maioria são de regiões periféricas da cidade, fator que vai ao encontro de Castro e Lopes (2011) ao tratarem que os docentes na maioria dos casos acreditam que a assistência ao aprendizado e alimentação contribui para melhor inserção dos alunos na sociedade, o que por outro lado pode contribuir também para a diminuição da função primária da escola que é o processo de ensino.

Esses dados podem se confirmar pelos relatos dos professores ao complementarem suas respostas para a questão tratada:

Pelo fato do aluno ficar o maior tempo na escola de tempo integral, os pais acham que é obrigação do professor educar com seus filhos. Tendo em vista a responsabilidade dos pais escassa. (Professor 1) (sic.) 


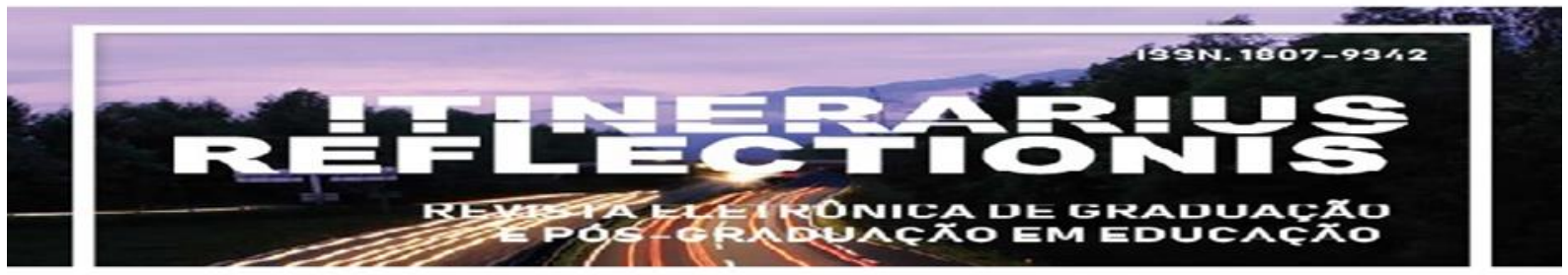

Volume, 15, número1, ano 2019

A escola acaba incumbida extremamente da função social. Os pais preocupam mais com um espaço para "depositar o filho e pouquíssimos participam ativamente da vida escolar do filho, visando o principal objetivo de uma escola, o desenvolvimento acadêmico quanto ao cognitivo. Dá-se a impressão que os pais preocupam mais que os professores sejam cuidadores do que professores, o que perderia a identidade da escola. (Professor 2) (sic.)

(...) Porque não tendo o acompanhamento da família deixa a desejar (Professor 3) (sic.)

Todas as ações da escola hoje visa na conduta do educando em sociedade, perdemos nossa identidade de professores e assumimos as responsabilidades dos pais, porem com menos poder (Professor 4) (sic.)

Julgamos pertinente analisar a disponibilidade do tempo para planejamento diante da extensão da grade curricular obedecendo os horários da escola. Cerca de 53,33\% apontaram que o tempo disponibilizado para planejamento na carga horária de trabalho não é suficiente para assegurar o planejamento de todas as disciplinas que os mesmos devem ministrar.

Compreendemos a importância de analisar se a Secretaria de Estado de Educação cumpre com o que é proposto nas Diretrizes Operacionais em relação à formação continuada e fornecimento de recurso para adequação dos espaços. Diante disso, 86,66\% dos professores afirmaram não ter acontecido nenhuma ação voltada a momentos de estudo e formação. Apenas $13,33 \%$ destes, consideraram como momento de estudo os repasses da coordenadora que acontecem na própria escola, após esta participar de uma capacitação para gestores realizada pela Secretaria de Estado da Educação.

Em linhas gerais, questionamos aos docentes quanto à infraestrutura da instituição e $100 \%$ assinalou que as instalações são inadequadas para a permanência de 10 horas de um considerável número de alunos na instituição. Questionamos quanto às reformas na infraestrutura para que se adeque à demanda para funcionamento em tempo integral e 73,33\% afirmaram não presenciar modificações nas instalações físicas em oposição a 26,66\% que apontaram haver reformas apenas no refeitório e que mesmo assim não é suficiente para comportar a demanda. Quando indagamos sobre o que poderia ser melhorado nestes quesitos as respostas foram semelhantes:

Tudo desde a infraestrutura à recursos didáticos (Professor 1)

Uma quadra de esporte, banheiros para os alunos tomarem banho. (Professor 2)

Espaço físico adequado, laboratórios e salas específicas. (Professor 3) 


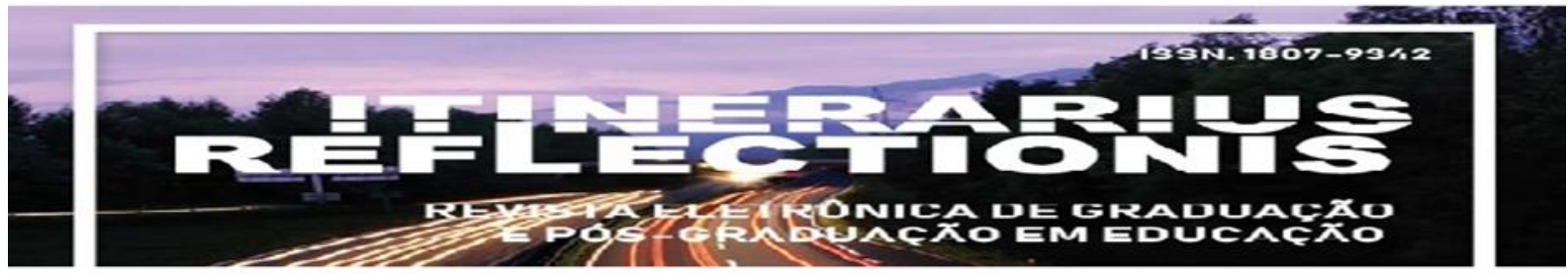

Volume, 15, número1, ano 2019

Questionamos se para a realização das atividades propostas, há recursos adequados quanto aos espaços disponíveis para todas as atividades. Os resultados foram condizentes aos achados da observação e $94 \%$ do corpo docente avaliaram que os espaços da escola são inadequados para a realização de todas as atividades executadas.

Com o intuito de verificar as percepções dos professores de forma geral, consideramos importante questioná-los abertamente sobre o que pensam acerca da escola de tempo integral. As percepções apresentaram sobremaneira marcas assistencialistas em virtude da oferta das refeições básicas e pelo fato de as crianças terem lugar para ficar enquanto os pais trabalham. Uma minoria apresentou uma visão contraditória que ora se mantém calcada na visão assistencialista, ora na carência dos recursos. Esses relatos podem se confirmar nas citações dos pesquisados:

Escola onde os pais põe seus filhos para fugirem das responsabilidades, a proposta do projeto é boa só no papel. (Professor 1) (sic)

Apesar de precisar de melhorias em questões como espaço, estrutura da escola e uma formação para nós professores. Eu vejo a escola de tempo integral como uma forma de educar, orientar e de socializar os alunos, já que a maioria dessas crianças não estão tendo uma família para orientá-los adequadamente e ficam na rua. (Professor 2) (sic)

Para que realmente tenha qualidade uma educação de escola de tempo integral no mínimo teria que ter infraestrutura e logo uma formação para professores, embora ela seja muito necessária para os pais trabalharem e deixarem seus filhos na escola, evitando a rua. (Professor 3) (sic)

A fim de verificar as percepções dos professores sobre a escola de tempo integral, indagamos aos entrevistados se matriculariam seu filho na escola de tempo integral, $60 \%$ não matriculariam seus filhos em oposição a $40 \%$ que afirmaram matricular.

O estudo com os professores nos possibilitou evidenciar que a grande maioria, embora sensibilizada com a causa social na qual a Escola de Tempo Integral está imbuída, muitos docentes apontam dificuldades no trabalho diante da precariedade das instalações física que esta escola se encontra. Conforme evidencia Santos (2011) é imprescindível que haja recursos adequados e que sejam subsidiados para que o trabalho com o alunado apresente melhorias. 


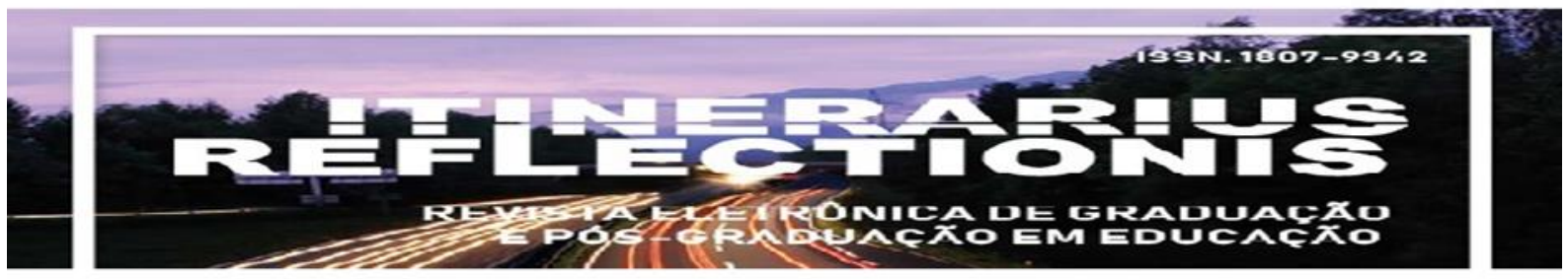

Volume, 15, número1, ano 2019

Dessa forma, é de suma importância que permanecer na escola por mais tempo concretize um projeto que possa contribuir realmente para o desenvolvimento das crianças. Neste aspecto, uma ferramenta importante é a formação continuada de professores para que estes tenham condições de compreenderem o contexto no qual a escola de tempo integral está inserida, sua história, os aspectos legais e sociais, os desafios enfrentados e as possiblidades de ensino mediante a extensão da permanência do aluno e, para tanto, poderem desenvolver melhores recursos didáticos para o trabalho pedagógico. De igual forma fica evidente que são necessários mais recursos financeiros para manutenção das dependências físicas para a promoção de ambientes de aprendizagem necessários para melhor desenvolvimento do processo ensino-aprendizagem (ARAUJO, PETRENAS E RIPA, 2009; AMARAL, 2012).

\section{CONCLUSÕES}

Este estudo evidenciou que a proposta de Escola de Tempo integral no contexto analisado apresenta algumas ausências, uma vez que não se encontra na legislação um projeto explícito para a comunidade que contenha os objetivos e público alvo a ser atendido. Concluímos que a experiência de Orizona-Go coaduna com vários trabalhos como o de Santos (2016) e Silva (2015), os quais relatam que a maioria das Escolas de Tempo Integral não oferece estrutura adequada para a permanência do aluno o dia todo na escola, pois funcionam em escolas que foram desativadas, cujos prédios estavam sem utilidade e não possuem espaços suficientes.

Para tanto, a carência de espaços por si só já demonstra o tumulto diário e a dificuldade dos professores para executarem atividades de cunho diferenciado como a própria natureza da escola carrega desde sua concepção enquanto política pública educacional. Por outro lado, sinalizamos uma possível melhora para o professor ao ser remunerado por $60 \mathrm{~h} / \mathrm{a}$ tendo tempos de estudo e planejamento no período escolar. Ressaltamos que o assistencialismo no que se refere a retirar crianças e adolescentes dos riscos sociais e oferecer-lhes alimentação e estudo enquanto os pais trabalham está presente na escola de tempo integral desde sua gênese e muito pouco provável se desvincule esta característica da organização escolar de tempo integral. Por isso, consideramos que é necessária formação continuada de professores para que os mesmos conheçam a história da educação que abrange a educação em tempo integral 


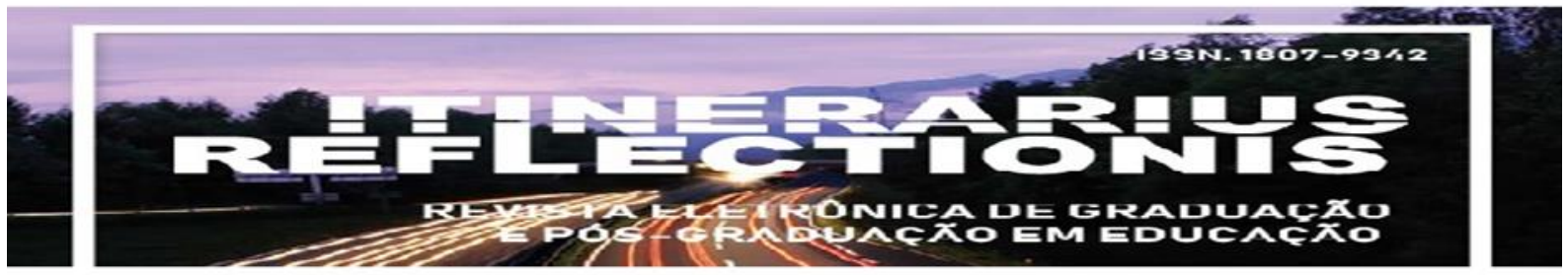

Volume, 15, número1, ano 2019

propriamente dita, os aspectos legais e possam articular os tempos para uma abordagem pedagógica com mais recursos didáticos.

Evidenciamos, portanto, que a identidade assistencialista para a ETI é atribuída por grande parte dos professores e nesse sentido consideramos que esta percepção se deve à carência de espaços físicos e melhoria daqueles que já existem na escola para que os estudantes possam ser melhor atendidos e professores terem melhores condições de exercerem o trabalho pedagógico. Desta forma consideramos que é necessário haver mais pesquisas destinadas a esta temática de forma a provocar reflexões na comunidade acadêmica e social, uma vez que vários discursos políticos afirmam a necessidade de ampliarem a jornada escolar.

\section{REFERÊNCIAS BIBLIOGRÁFICAS}

AMARAL, Elaine Abrahão. Escola em tempo integral: espaço de construção ou de precarização do processo educacional. Revista de Magistro de Filosofia, n. 8. Faculdade Católica de Anápolis, 2012.

BRASIL. Constituição (1988). Constituição da República Federativa do Brasil. 05 de outubro de 1988.

BRASIL. Decreto n ${ }^{\circ}$ 7.083, de 27 de janeiro de 2010. Fundo Nacional de Desenvolvimento da Educação.

BRASIL. Lei de Diretrizes e Bases da Educação Nacional. Lei no 9394, 20 de dezembro de 1996.

\section{BRASIL. Lei ${ }^{\circ}$ 12.796, de 04 de abril de 2013.}

BRASIL. Medida Provisória nº 746, de 22 de Setembro de 2016.

BRASIL. Portaria normativa interministerial $\mathrm{n}^{\circ}$ - 17, de 24 de abril de 2007. Ministério da Educação e Cultura, 2007.

CARBELLO, Sandra Regina Cassol; RIBEIRO, Ricardo. Escola Parque: notas sobre a proposta de Anísio Teixeira para o ensino básico no Brasil. Revista Ibero-Americana de Estudos em Educação, v. 9, n. 2, 2014.

CASTRO, Adriana de; LOPES, Roseli Esquerdo. A escola de tempo integral: desafios e possibilidades. Revista Ensaio: Avaliação e Políticas Públicas em Educação, v. 19, n. 71, p. 259-282, 2011.

CAVALIERE, Ana Maria Villela. Educação integral: uma nova identidade para a escola brasileira. Educação e Sociedade, v. 23, n. 81, p. 247-270, 2002. 


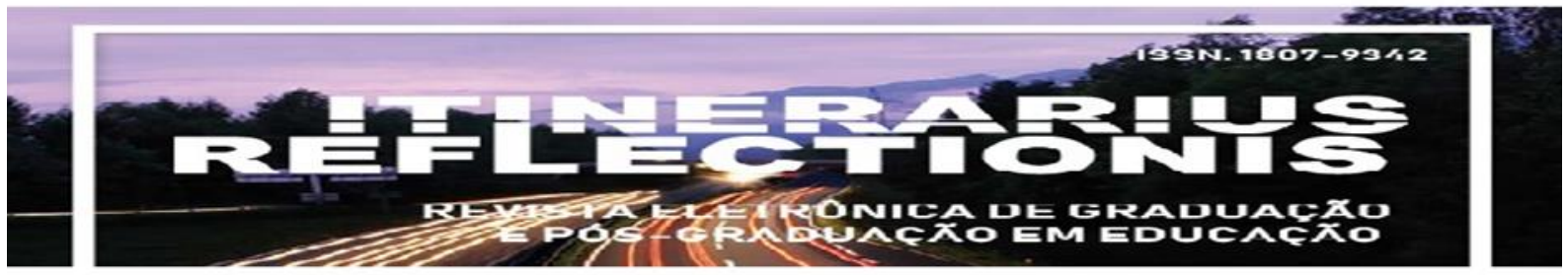

Volume, 15, número1, ano 2019

CONFERÊNCIA NACIONAL DE EDUCAÇÃO (CONAE). O PNE na articulação do Sistema Nacional de Educação. Documento Final. Brasília (DF): MEC/CONAE, 2014.

SANTOS, Wellyanna Costa dos et al. Educação integral: contribuições para as escolas públicas da rede municipal e estadual de Jaguarão/RS. Anais do Salão Internacional de Ensino, Pesquisa e Extensão, v. 7, n. 2, 2016.

GIL, Antônio Carlos. Métodos e Técnicas de Pesquisa Social. $6^{\text {a }}$ ed. São Paulo, Editora Atlas, 2008.

GOIÁS. Orientações Pedagógicas Preliminares. Secretaria de Estado de Educação, Cultura e Esporte, Goiânia, 2016.

GOIÁS. Lei n 19.687, de 22 de junho de 2017.

LIBÂNEO, José C. Escola de tempo integral em questão: lugar de acolhimento social ou de ensino-aprendizagem. Educação: ensino, espaço e tempo na escola de tempo integral.

Goiânia: Cegraf/UFG, 2014.

MOYSÉS, Gerson Luís Russo; MOORI, Roberto Giro. Coleta de dados para a pesquisa acadêmica: um estudo sobre a elaboração, a validação e a aplicação eletrônica de questionário. XXVII Encontro Nacional de Engenharia de Produção, 2007.

PARO, Vitor Henrique et. al. Escola de tempo integral: desafio para o ensino público. Cortez, 1988.

Plano Nacional de Educação (PNE). Planejando a próxima década: conhecendo as 20 metas do Plano Nacional de Educação. Ministério da Educação, Secretaria de Articulação com os Sistemas de Ensino, Brasília (DF), 2014.

Plano Nacional de Educação. Senado Federal, Brasília, 2001.

SANTOS, Soraya Vieira. A ampliação do tempo escolar em propostas de educação pública integral. Dissertação (Mestrado em Educação) - Faculdade de Educação, Goiânia, Universidade Federal de Goiás, 2009.

SÁ-SILVA, Jackson Ronie; DE ALMEIDA, Cristóvão Domingos; GUINDANI, Joel Felipe. Pesquisa documental: pistas teóricas e metodológicas. Revista Brasileira de História \& Ciências Sociais, v. 1, n. 1, 2015.

SEDUCE, Secretária de Estado de Educação, Cultura e Esporte. Novo Futuro. Disponível em: 〈http://www.seduc.go.gov.br/imprensa/?Noticia=4164>

SEDUCE. Escolas de Tempo Integral. Disponível em:

<http://portal.seduc.go.gov.br/SitePages/Pagina.aspx?idPagina=57>

SILVA, Diguerson Gomes da; ROCHA, Lucas Bispo. A escola de tempo integral em Goiás: o pacto pela educação, o programa novo futuro e a criação do Centro de Ensino em Período Integral (CEPI). Observatório em Debate, n. 1, p. 134-143, 2014. 


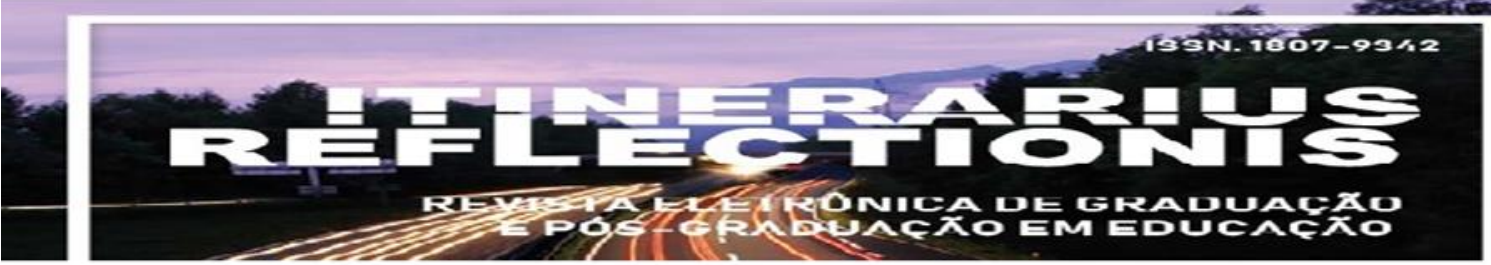

Volume, 15, número1, ano 2019

SILVA, Flávia Osório da Silva. Escola de Tempo Integral: uma na análise da implantação na Rede Estadual de Goiás (2006-2010). Dissertação (Mestrado em Educação) - Faculdade de Educação, Universidade Federal de Goiás, Goiânia, 2011.

SILVA, Marina Santos da. Concepções de professores, coordenadores, vice-diretor e diretor do ensino fundamental sobre a escola em tempo integral: um estudo na Cidade de Potim. Dissertação (Mestrado em Educação), Universidade de Trás-os-Montes e Alto Douro São Paulo, Vila Real. 2015.

SILVA, Sivia Maria Andriotti da. Educação integral/integrada no cotidiano escolar. Universidade Federal do Rio Grande do Sul, Repositório Digital, 2013. 